\title{
Physical activity and sedentary behavior in university students during the COVID-19 pandemic
}

\section{Atividade física e comportamento sedentário em universitários durante a pandemia da COVID-19}

\section{AUTHOR'S \\ Daniela Lopes dos Santos ${ }^{1}$ (D) \\ Cati Reckelberg Azambuja ${ }^{2}$ (D) \\ 1 Universidade Federal de Santa Maria, Núcleo de Estudos em Exercício Físico e Saúde, Centro de Educação Física e Desportos, Santa Maria, Rio Grande do Sul, Brasil. \\ 2 Faculdade Metodista Centenário, Núcleo de Estudos em Exercício Físico e Saúde, Santa Maria, Rio Grande do Sul, Brasil.}

\section{CORRESPONDING}

Daniela Lopes dos Santos

lopesdossantosdaniela@gmail.com

Rua Presidente Vargas, n. 1635/303. Santa

Maria, Rio Grande do Sul, Brasil.

CEP: 97015-511.

DOI

$10.12820 /$ rbafs. $25 \mathrm{e} 0177$

\section{(cc) BY}

This work is licensed under a Creative Commons Attribution 4.0 International License.

\begin{abstract}
The aim of this study was to analyze the impact of the COVID-19 pandemic on the study routine and physical activity of Physical Education students. The study included, by convenience sampling, 721 undergraduate Physical Education students from the state of Rio Grande do Sul. For data collection, a questionnaire containing questions about sample characterization, study routine and characteristics of physical activity before and during social distancing/isolation was used. This instrument was made available by Google Forms, between April $13^{\text {th }}$ and May $31^{\text {st }}$ of 2020 . The data were analyzed using descriptive and inferential statistics. It was found that $35 \%$ of the students had their studies completely interrupted and $27.9 \%$ of them reported an increase in their load of study routine activities. The time spent on television went from one to two hours a day $(47.7 \%)$ to up to four hours (63.7\%), with women having greater screen time for television ( $>3 \mathrm{~h} /$ day; $\mathrm{p}=0.027$ ) during the pandemic period. There was an increase from $3.1 \%$ to $18.7 \%$ of students who were not practicing any physical activity. Those who remained active decreased the number of days of weekly practice and the average time per session $(p<0.001)$. Thus, it is necessary to think about strategies to increase and maintain the levels of physical activity, as means of protection and reduction of health damages, caused by the infection of the new coronavirus and by the social distancing/isolation imposed to reduce the transmission of the virus.
\end{abstract}

Keywords: Students; Coronavirus; Motor activity; Cross-sectional study.

RESUMO

O objetivo desse estudo foi analisar o impacto da pandemia da COVID-19 na rotina de estudos e na prática de atividades físicas de estudantes de Educação Física. Participaram do estudo, através de amostragem por conveniência, 721 acadêmicos de cursos de graduação em Educação Física do estado do Rio Grande do Sul. Para a coleta de dados foi utilizado um questionário incluindo perguntas de caracterização da amostra, rotina de estudo e características da prática de atividades físicas antes e durante o isolamento/distanciamento social. Este instrumento foi disponibilizado pelo Google Forms, entre $1^{\circ}$ de abril e 31 de maio de 2020. Os dados foram analisados por estatistica descritiva e inferencial. Foi constatado que 35\% dos alunos interromperam totalmente os estudos e 27,9\% reportaram que suas rotinas alteraram para uma maior carga de atividades de estudos. O tempo destinado à televisão passou de uma a duas horas por dia (47,7\%) para até quatro horas (63,7\%), sendo que as mulheres apresentaram tempo de tela para televisão (>3h/dia; $p=0,027)$ maior durante o periodo da pandemia. Houve um aumento de 3,1\% para 18,7\% de estudantes que não estavam praticando nenbuma atividade fisica. Aqueles que se mantiveram ativos, diminuiram a quantidade de dias de prática semanal e o tempo médio por sessão $(p<0,001)$. Assim, há de se pensar em estratégias de aumento e manutenção dos níveis de atividade física, como forma de proteção e redução dos danos à saúde, causados pela infecção do novo coronavirus e pelo isolamentoldistanciando social imposto para diminuir a transmissão do virus.

Palavras-chave: Estudantes; Coronavirus; Atividade motora; Estudo transversal.

\section{Introduction}

In the last few months, the world population has been dealing with two expressions, which until now were used only by a few groups of people, especially scientists: "Social Distancing" and "Lock Down". These terms mean distancing or even the absence of personal contacts and physical closeness between people, in or- der to mitigate the possibility of transmitting a disease. Examples of restrictive measures are those that include canceling public meetings and agglomerations, closing schools, universities and commerce, transferring work to the home office system, among many others ${ }^{1}$.

Severe measures, such as these, are experienced by all nations during the year of 2020. The outbreak of 
the new coronavirus (SARS CoV-2 or simply, COVID-19), started in Wuhan (Hubei, China) and spread to several countries, becoming a pandemic ${ }^{2}$. When community transmission was confirmed, it became necessary that the restrictions be extended, to mitigate the worsening of the situation. Thus, in addition to the measures already mentioned, the tracking of individuals suspected of being infected was implemented and greater restriction to the population was promoted ${ }^{1}$.

Part of this control strategy is the implementation of municipal and state decrees with guidelines, canceling sporting events, closing gyms, personal trainers' studios, clubs and even prohibiting outdoor physical activities, such as walking, running and cycling. Direct interference with people's lifestyles can lead to decreased levels of physical activity (PA) and contribute to loss of physical fitness ${ }^{3}$, increase in body weight and in comorbidities such as obesity, hypertension, insulin resistance and psychosocial disorders, such as anxiety and depression ${ }^{4}$.

On the other hand, it is necessary to consider the circumstances and priorities that must be established during a global pandemic. So far, little is known about the virus's behavior. There are many asymptomatic cases of COVID-19, which make symptom-based control insufficient. Estimates suggest that about $80 \%$ of people with COVID-19 will have no symptoms at all ${ }^{5}$.

Several research and health institutions around the world are worried about the negative repercussions of the inactive lifestyle due to the pandemic, so they have elaborated guidelines. For instance, in a recent Editorial of the Brazilian Archives of Cardiology, journal of the Brazilian Society of Cardiology, the authors recommended a series of activities to maintain a physically active lifestyle during social distancing and isolation (SDI), regardless of age. They are: performing pleasurable PA, exploring home spaces and household items; accomplish daily living activities such as cleaning, maintenance and organization of domestic spaces; playing and exercising with children, adolescents and pets, using games that promote energy expenditure above the resting condition; avoid sedentary behavior, alternating sitting or lying down time with periods of $\mathrm{PA}$, reducing the time of electronic devices usage; set aside a few minutes for stretching, relaxation and meditation activities ${ }^{4}$.

However, it must be highlighted that the facilities that technology provides are an important ally in the communication between people, but an enemy when it comes to increasing the sedentary behavior in the population. On the other hand, attention has to be given to exercise prescriptions and PA recommendations' sources, since these should be elaborated by a Physical Education professional, even when it is done online, prioritizing supervision, results, safety and motivation in training ${ }^{6}$.

As for students that were accustomed to face-toface learning, there may be some difficulties in organizing the study moments, as they are still developing autonomy ${ }^{7}$, which in academic tasks translates into the lack of an andragogical profile, presented by those who are motivated to study in the online format. This, together with the imposition to stay home due to the SDI may contribute for the reduction of PA levels and increase in sedentary behavior, which can cause several health problems, especially for those who were used to being active, even during learning time.

Therefore, after describing the moment that all sectors of society are facing in relation to public health, the consequences of coexistence restrictive measures and the possibilities of coping with all that, considering especially active and sedentary behaviors, the purpose of this study was to analyze the impact of the COVID-19 pandemic on Physical Education students' PA levels and study routines.

\section{Methods}

The SDI due to the COVID-19 pandemic started in the State of Rio Grande Sul, Brazil, on the third week of March, when all education institutions (schools, universities, colleges) interrupted their face-to-face activities. All students stayed at home and most of them had e-learning (formal teaching but with the help of electronic resources). Considering the data collection period, they were in SDI for 30 to 75 days, when they participated in the study.

The studied population was of Physical Education undergraduate students who were on SDI in the state of Rio Grande do Sul, Brazil. All 36 institutions (universities, colleges and teaching centers) that offered Physical Education undergraduate courses in 2020 were invited to participate in the study and 24 of them agreed. All seven regions of the State were represented by, at least, two institutions. Then, an invitation was sent to the students through their course coordinator, with the link to access the questionnaire. According to the coordinators, around 4,000 students were effectively invited to participate, of which, 721 accepted. The 
infinite probabilistic sampling technique was used to calculate the sample size. The confidence level was $95 \%$ $(\alpha=0.05)$, with a maximum error of $3 \%(\mathrm{e} 0=0.03)$ and an estimated sample proportion of $50 \%(\mathrm{p}=0.5)$, which determined a sample of 544 individuals. The institutions' refusals occurred due to the lack of effective communication channels and/or of the response to the invitation email. Fifteen days after the first invitation email had been sent, a second invitation email was sent to the institutions that had not answered yet. Among the students who accessed the form, all agreed to answer the questions and completed them satisfactorily.

The questionnaire used for data collection, included sample characteristics (age, sex, living city, university and semester in which they were studying), study routine and PA characteristics, one week before the beginning of SDI and at that moment they were answering, in SDI. The researchers built this instrument, since there were none about COVID-19 already validated and available. It was initially tested among 10 participants of the Laboratory of Physical Exercise and Health, which had the same profile of the study's subjects, that is, university students. They were asked to answer the questionnaire and state if it was clear, easy to understand and if the questions were adequate to the study's goals. After the final adjustments, it was made available to the study participants by Google forms between April $13^{\text {th }}$ and May $31^{\text {st }}$ of 2020. The Informed Consent Form was presented before the questions with a description of the objectives and procedures for participation, including the identity confidentiality agreement. Afterwards, the question "Do you agree to participate in this study?" was presented. When clicking on "yes" the questionnaire started and, if the participant clicked "no", the questionnaire ended automatically. In either case, the confidentiality of the participants was guaranteed by the total absence of identification items on the form, such as name and e-mail. There was also no possibility of control of the participants by the course coordinators.

Data were expressed by measures of central tendency and dispersion, and Kolmogorov-Smirnov test was used to describe distribution. The comparisons between ages were done by Mann Whitney $U$ test, and for multiple comparisons the Kruskal-Wallis test (male vs. female) and the Friedman test (before vs. during) were used, plus Dunn's post hoc test. The comparisons of proportions between data collection periods in each sex group and in total were tested with the Chi-square test for homogeneity of proportions. All analyses were performed using the SPSS program (Statistical Package for the Social Sciences) 20.0 and a 5\% level of significance was adopted.

The research was conducted in accordance with the Helsinki Declaration principles and Resolution 466/12 of the Ministry of Health ${ }^{8}$ that regulates research with human beings in Brazil. The study was approved by the Ethics Committee on Human Research of Federal University of Santa Maria (protocol no. 4.004.941 and CAAE no. 31274820.9.0000.5346).

\section{Results}

The participants were Physical Education undergraduate students from universities, colleges or education centers, mostly from public institutions (59.9\%; n = 432). When stratified by sex, $50.2 \%(n=362)$ were men, which were older $(25.9 \pm 7.7$ years; $\mathrm{p}=0.004)$ when compared to the female group ( $24.6 \pm 6.7$ years). Most of these students $(58.7 \% ; n=423)$ had already taken more than four semesters, that is, more than half of the course.

Thirty-five percent of the students stopped entirely their study routine. Among those who continued having classes, some students stated that their routine did not change $(3.6 \% ; \mathrm{n}=26)$ and others that there was a decrease in their study activities $(33.6 \% ; n=242)$. However, surprisingly, 201 (27.9\%) students reported that their study routines changed to a greater load of activities.

SDI reflected in several other behaviors, such as screen time, PA levels and the types of exercises practiced by the students. Table 1 shows their daily time spent watching television, using computers for class online or social media and the weekly time spent with PA.

The time spent on television, which before the pandemic was one to two hours a day (47.7\%), increased to four hours $(63.7 \%)$ during social distancing. The same occurred with social media, which was one to four hours a day (62.1\%), turned into three to six (53.1\%). However, when stratified by sex, only television time (over three hours a day) increased for women during the pandemic. Regarding physical activities, the differences that occurred before and during the pandemic, for both sexes, were significant (Table 2).

It is interesting to observe that there was an increase from $3.1 \%$ to $18.7 \%$ of the subjects who were not practicing any PA. Table 3 shows the students' PA routine.

We may observe that before the pandemic, most of 
the students practiced PA three and six days a week. two or less days per week increased. The average time During the period of SDI, the highest percentage of per session, which used to be 120 to 180 minutes, dethem went to three to four days, and the frequency of creased to 60 to 120 minutes in most cases.

Table 1 - Comparisons of screen time and physical activity of Physical Education students of before and during COVID-19 pandemic.

\begin{tabular}{|c|c|c|c|c|c|c|c|}
\hline \multirow{2}{*}{$\begin{array}{l}\text { Screen Time and } \\
\text { Physical Activity Levels }\end{array}$} & \multicolumn{3}{|c|}{$\begin{array}{l}\text { Feminine } \\
(\mathrm{n}=359)\end{array}$} & \multicolumn{3}{|c|}{$\begin{array}{c}\text { Masculine } \\
(\mathrm{n}=362)\end{array}$} & \multirow[t]{2}{*}{ p-value } \\
\hline & $x$-bar & $\mathrm{SD}$ & $\mathrm{p}$-value & $\mathrm{x}$-bar & $\mathrm{SD}$ & $\mathrm{p}$-value & \\
\hline \multicolumn{8}{|c|}{ Physical Activity (min/week) } \\
\hline Before COVID-19 & 1359.0 & 920.2 & \multirow{2}{*}{$<0.001$} & 1732.0 & 1047.0 & \multirow{2}{*}{$<0.001$} & 0.153 \\
\hline During COVID-19 & 319.2 & 279.7 & & 385.2 & 318.2 & & 0.860 \\
\hline \multicolumn{8}{|l|}{ Television (min/day) } \\
\hline Before COVID-19 & 126.2 & 112.1 & \multirow{2}{*}{$<0.001$} & 124.8 & 121.0 & \multirow{2}{*}{$<0.001$} & $>0.999$ \\
\hline During COVID-19 & 188.5 & 139.0 & & 174.7 & 140.8 & & $0.027^{*}$ \\
\hline \multicolumn{8}{|l|}{ Computer (min/day) } \\
\hline Before COVID-19 & 201.1 & 128.1 & \multirow{2}{*}{$>0.999$} & 180.0 & 122.8 & \multirow{2}{*}{$>0.999$} & 0.914 \\
\hline During COVID-19 & 217.6 & 161.1 & & 189.1 & 147.9 & & 0.188 \\
\hline \multicolumn{8}{|l|}{ Social Media (min/day) } \\
\hline Before COVID-19 & 241.0 & 144.1 & \multirow{2}{*}{0.021} & 250.1 & 150.5 & \multirow{2}{*}{0.004} & $>0.999$ \\
\hline During COVID-19 & 298.1 & 159.6 & & 303.3 & 161.3 & & $>0.999$ \\
\hline
\end{tabular}

Values represented in $\mathrm{x}-\mathrm{bar} \pm \mathrm{SD}=$ mean and standard deviation; multiple comparisons between masc. vs fem. = Kruskal-Wallis test; multiple comparisons between before vs during $=$ Friedman test; post hoc $=$ Dunn's multiple comparison test; significance level 5\%; ns = non significant .

Table 2 - Variation Index of the level of physical activity of Physical Education Students before and during the COVID-19 pandemic.

\begin{tabular}{|c|c|c|c|c|c|c|}
\hline \multirow{2}{*}{$\begin{array}{l}\operatorname{PAL}(\mathrm{n}=721) \\
(\mathrm{min} / \text { week })\end{array}$} & \multicolumn{2}{|c|}{$\begin{array}{c}\text { Before COVID-19 } \\
\text { (af) }\end{array}$} & \multicolumn{2}{|c|}{$\begin{array}{c}\text { During COVID-19 } \\
\text { (af) }\end{array}$} & \multicolumn{2}{|c|}{$\begin{array}{l}\text { Delta } \\
(\%)\end{array}$} \\
\hline & Female & Male & Female & Male & Female & Male \\
\hline None & 12 & 11 & 71 & 65 & 491.7 & 490.9 \\
\hline$<150$ & 6 & 4 & 50 & 34 & 733.3 & 750.0 \\
\hline 151 a 300 & 12 & 8 & 40 & 58 & 233.3 & 625.0 \\
\hline 301 a 600 & 37 & 23 & 128 & 143 & 245.9 & 521.7 \\
\hline 601 a 900 & 63 & 41 & 33 & 41 & -47.6 & 0.0 \\
\hline 901 a 1200 & 107 & 99 & 5 & 12 & -95.3 & -87.9 \\
\hline > 1201 & 122 & 176 & 4 & 9 & -96.7 & -94.9 \\
\hline
\end{tabular}

$\mathrm{PAL}=$ physical activity level in minutes per week; $(\mathrm{af})=$ absolute frequency; Delta $(\%)$ = percentage variation from before to during COVID-19.

Table 3 - Physical Education Students' physical activity routine before and during COVID-19 pandemic.

\begin{tabular}{|c|c|c|c|c|c|c|c|c|c|}
\hline \multirow{2}{*}{$\begin{array}{l}\text { Physical Activity } \\
\text { Routine }\end{array}$} & \multicolumn{3}{|c|}{$\begin{array}{c}\text { Female } \\
(\mathrm{n}=359)\end{array}$} & \multicolumn{3}{|c|}{$\begin{array}{c}\text { Male } \\
(\mathrm{n}=362)\end{array}$} & \multicolumn{3}{|c|}{$\begin{array}{c}\text { All } \\
(\mathrm{n}=721)\end{array}$} \\
\hline & Before & During & $\begin{array}{c}x^{2} \text { value } \\
\text { (p-value) }\end{array}$ & Before & During & $\begin{array}{c}x^{2} \text { value } \\
\text { (p-value) }\end{array}$ & Before & During & $\begin{array}{l}x^{2} \text { value } \\
(\mathrm{p} \text {-value })\end{array}$ \\
\hline \multicolumn{10}{|l|}{ Times per week } \\
\hline None & 3.34 & 19.50 & \multirow{5}{*}{$\begin{array}{c}67.9 \\
(<0.001)\end{array}$} & 3.04 & 17.96 & \multirow{5}{*}{$\begin{array}{c}80.6 \\
(<0.001)\end{array}$} & 3.19 & 18.72 & \multirow{5}{*}{$\begin{array}{c}141.2 \\
(<0.001)\end{array}$} \\
\hline 1-2 days & 15.32 & 22.28 & & 10.22 & 17.40 & & 12.76 & 19.83 & \\
\hline 3-4 days & 44.57 & 37.05 & & 29.28 & 35.36 & & 36.89 & 36.20 & \\
\hline 5-6 days & 33.15 & 16.71 & & 48.07 & 23.76 & & 40.64 & 20.25 & \\
\hline Daily & 3.62 & 4.46 & & 9.39 & 5.52 & & 6.52 & 4.99 & \\
\hline \multicolumn{10}{|c|}{ Mean time per session } \\
\hline None & 3.34 & 19.50 & \multirow{4}{*}{$\begin{array}{c}138.4 \\
(<0.001)\end{array}$} & 3.04 & 17.96 & \multirow{4}{*}{$\begin{array}{c}131.1 \\
(<0.001)\end{array}$} & 3.19 & 18.72 & \multirow{4}{*}{$\begin{array}{c}269.2 \\
(<0.001)\end{array}$} \\
\hline $60 \mathrm{~min}$ & 4.18 & 22.28 & & 1.93 & 16.57 & & 3.05 & 19.42 & \\
\hline $120 \mathrm{~min}$ & 62.40 & 50.70 & & 54.97 & 53.04 & & 58.67 & 51.87 & \\
\hline $180 \mathrm{~min}$ & 30.08 & 7.52 & & 40.06 & 12.43 & & 35.09 & 9.99 & \\
\hline
\end{tabular}

Values represented in \% (percentage); min = minutes; $x^{2}$ value $=$ Chi square test for homogeneity of proportions; significance level $5 \%$. 


\section{Discussion}

At the beginning of the first school semester of 2020, on-site activities at Higher Education Institutions were suspended, totally interrupting the study routine of one third of the students surveyed, which may represent a loss, not only for technical training, but also for the other skills that they are expected to develop during an undergraduate course.

According to Dorn et al. ${ }^{9}$, how much learning is lost with the closure of schools and universities tends to vary significantly according to access to remote learning, the quality of remote education itself, home support and the degree of student engagement. Through statistical simulation, the authors concluded that the students with medium quality in remote education continue to progress, but more slowly when compared to a student with traditional classroom classes; the ones with low quality remote education stagnate in their learning and students who are not receiving any instruction, have significant losses in relation to the learning achievements they had. The learning setbacks are greater the longer is the downtime.

When analyzing the report of students who stated that the burden of activities increased, it is likely that many teachers, fearful of not meeting their expectations, may have applied a greater burden of tasks. In a study by Santos et al. ${ }^{10}$, in which the challenges faced by 36 professors in remote activities were reported in a face-to-face undergraduate course, it was found that only $16.7 \%$ of them used other resources, such as social networks, chats, forums and online tests.

In addition to changes in the study routine, changes in other behaviors were observed. The increases in average times of computer use, in both sexes, were not significant. However, it should be considered that one third of the students reported that their academic activities had been completely interrupted and many of them already had the habit of using portable computers in classroom classes and, therefore, this screen time would not differ between the traditional and the remote classroom.

The screen time devoted to television and social media, during the SDI period, increased when compared to the normal period, regardless of sex, therefore increasing the time of sedentary behaviors. Thus, there was a significant decrease in PA level, despite the fact that the average still met $\mathrm{WHO}^{11}$ recommendations for adults, that is, between 150 and 300 minutes per week of light to moderate PA or 75 minutes of vigorous PA.
A study conducted in India ${ }^{12}$, with physiotherapy undergraduate students and professionals, which had its data collection in the same period of the present study, demonstrated a decrease in vigorous and moderate PA during the pandemic, as well as an increase in sitting time, compared to the period before SDI, corroborating our data.

Even before the COVID-19 pandemic, young people around the world already had a tendency to increase sedentary behavior ${ }^{13-14}$, especially because in the last decades there has been an important increase in the use of computers and electronic devices. In Brazil, the same situation was observed, even in Physical Education undergraduate students ${ }^{15}$. Throughout the implementation of SDI measures due to the pandemic, the populations started to depend more and more on domestic internet connections to carry out work, study, get information, enjoy leisure and even to interact with family and friends online. Global reports estimate a total increase in Internet traffic by 40 to $60 \%$ after the start of such measures ${ }^{16}$.

These data are worrisome since Colley et al. ${ }^{17}$ demonstrated that Canadian adults who avoid excessive screen time and engage more in physical activities, especially outdoors, during the COVID-19 pandemic, tend to have a better perception of general and mental health. The authors highlight the importance of these results, considering the impossibility of predicting when the pandemic will slow down, and that measures of SDI are likely to be necessary for a long time in the near future.

An interesting study ${ }^{18}$ carried out in Belgium compared the effects of SDI imposed by the pandemic on the levels of PA and it was found that, among people already active, $36 \%$ reported an increase in PA levels, $41 \%$ remained the same and only $23 \%$ exercised less with SDI measures. In the group of people classified as insufficiently active before the pandemic, 58\% were exercising more, $5 \%$ as much and $7 \%$ less than before SDI. The other 30\% did not perform any PA and continued that way. These data confirm that those who were already active before SDI tend to increase or maintain their level of PA even in an atypical moment such as a global pandemic with forced social isolation.

It is worth noting that a Physical Education undergraduate course has characteristics of many physical activities and dynamic classes, and it is expected that these students have greater affinity with sports and PA. Thus, several national studies with Physical Education 
students have shown that this population generally has high PA levels, such as Melo et al. ${ }^{19}$ in Vitória - Espírito Santo and Santos et al. ${ }^{20}$ in Pelotas - Rio Grande do Sul.

In this study, the greatest decreases occurred at the highest intervals of PA levels (above 901 minutes or 15 hours per week), probably as a consequence of the restrictions on circulation in public spaces and closure of gyms, physical training studios and sports clubs. The increase of approximately six times in the cases of sedentary students is noteworthy, but it can be underpinned by the atypical moment experienced by humanity. Anyway, it is important to note that before the pandemic there was already a great number of students who did not perform any PA. This is a concerning situation from both health and academic points of view. Some of the studies previously cited, concerning Physical Education students, also reported low levels of PA and sedentary lifestyle in a non-epidemic situation, corroborating the data relative to before the pandemic in this study.

Gallo et al. ${ }^{21}$ analyzed the difference in PA levels of university students in Australia, between the years 2018-19 and 2020, already during the measures of SDI, and they found a statistically significant reduction in 2020, in both sexes. When they analyzed walking and vigorous PA separately, there was a significant reduction in walking in both sexes and in vigorous $\mathrm{PA}$ in men, since women already had a low participation in vigorous $\mathrm{PA}$ even before the pandemic.

Ammar et al. ${ }^{22}$ conducted a survey with an online questionnaire involving adults from various continents (Africa, Asia, Europe, the Americas), in which they analyzed not only the changes in PA levels with SDI, but also in practice routines. There was a decrease of $24 \%$ in the number of days per week in which they exercised during SDI and as for the number of minutes per week, it decreased from an average of 108 to 71.8. These findings are in line with those of the present study, in which a decrease was observed both in the number of days per week of PA, as well as in the number of minutes per week and in the duration of the sessions.

Qin et $a .^{23}$ found that the prevalence of insufficiently active individuals tripled when compared to the pre-pandemic period (31.7\% higher in men and 39.1\% higher in women). Ruiz-Roso et al. ${ }^{24}$ also described the changes in PA levels, but of Europeans (Italians and Spaniards) and Latin (Brazilians, Chileans and $\mathrm{Co}^{-}$ lombians) teenagers and youngsters. The proportion of subjects considered physically inactive was $73.0 \%$ before SDI and 79.5\% during this period. Brazil and Chile were the countries with the highest frequency of inactive young people during SDI. In Brazil, physical inactivity increased from $40.9 \%$ before the pandemic period to $93 \%$ during.

In another study conducted with Chilean adults ${ }^{25}$ it was demonstrated that $51.2 \%$ of men and $58.7 \%$ of women reported a decrease in PA levels during SDI, and it was also detected that these levels were inversely proportional to the increase in body mass, that is, the lower the PA level, the greater tends to be the body mass. This observation becomes relevant as the relationship between obesity and the worsening of the symptoms of COVID-19 has been speculated in the scientific community ${ }^{26,27}$.

In periods of SDI and quarantine, there tends to be an increase in the sense of insecurity, fear of contagion, stigma and information overload, which leads to greater psychological stress, anxiety and depression ${ }^{28}$. A study carried out in Brazil, showed that during SDI due to the pandemic, people who reported performing more than 30 minutes of moderate to vigorous PA per day or more than 15 minutes of vigorous PA were less likely to experience anxiety, depression and symptoms related to these psychological disorders, while those with long periods of sedentary behavior were more prone to such symptoms ${ }^{29}$.

The limitations of this study include the use of online questionnaire for data collection, which is not an objective measure and possible information bias related to data of the previous period (before SDI). However, its strength should be considered, since it is the first Brazilian study about the effects of SDI due to COVID in university students, especially Physical Education students.

It is concluded that with the SDI imposed by the pandemic of the new coronavirus, the sedentary behavior increased six times in the Physical Education students of the state of Rio Grande do Sul and one third of these had their studies discontinued. Watching television and surfing social networks were the sedentary behaviors that increased the most, the first being highest among women. There was also a greater load of academic activities and a significant decrease in PA levels during the COVID-19 pandemic, with a decrease in the number of days per week, minutes per day and per week of PA.

Thus, in the interest of personal and public health, strategies to increase and maintain the population's PA 
levels should be considered, with the aim of reducing the damage caused both by the new coronavirus itself as by the SDI imposed to reduce viral transmission.

\section{Conflict of interest}

The authors declare no conflict of interest.

\section{Authors' contributions}

Santos DL, study conception and design, data collection and input, data interpretation and discussion, manuscript draft and critical review. Azambuja CR, study conception and design, data collection and input, statistical analysis, data interpretation and discussion, manuscript draft and critical review.

\section{Acknowledgements}

The authors would like to thank all the study participants.

\section{References}

1. Heymann DL, Shindo N. COVID-19: what is next for public health? Lancet. 2020;395(10224):542-5.

2. Velavan TP, Meyer CG. The COVID-19 epidemic. Tropical Med Int Health. 2020;25(3):278.

3. Raiol RA. Physical exercise is essential for physical and mental health during the COVID-19 pandemic. Braz.J. Hea. Rev. 2020;3(2):2804-13.

4. Ferreira MJ, Irigoyen MC, Consolim-Colombo F, Saraiva JFK, Angelis KD. Vida Fisicamente Ativa como Medida de Enfrentamento ao COVID-19. Arq Bras Cardiol. 2020 [cited 2020 aug 28]. Available from: http://publicacoes. cardiol.br/portal/abc/portugues/aop/2020/AOP_20200235.pdf. [Epub ahead of print].

5. Anderson RM, Heesterbeek H, Klinkenberg D, Hollingsworth TD. How will country-based mitigation measures influence the course of the COVID-19 epidemic? Lancet. 2020;395(10228):931-4.

6. Chen P, Mao L, Nassis GP, Harmer P, Ainsworth BE, Li F. Wuhan coronavirus (2019-nCoV): The need to maintain regular physical activity while taking precautions. J Sport Health Sci. 2020;9(2):103.

7. Joye CR, Moreira MM, Rocha SSD. Educação a Distância ou Atividade Educacional Remota Emergencial: em busca do elo perdido da educação escolar em tempos de COVID-19. Res Soc Dev. 2020;9(7):e521974299.

8. Brasil. Ministério da Saúde. Conselho Nacional de Saúde. Resolução no 466, de 12 de dezembro de 2012. DOU, 13 jun 2012, Brasília, DF, 12 dez. 2012.

9. Dorn E, Hancock B, Sarakatsannis J, Viruleg E. COVID-19 and student learning in the United States: The hurt could last a lifetime. McKinsey \& Company. 2020. [cited 2020 aug 21]. Available from: https://www.mckinsey.com/industries/ public-and-social-sector/our-insights/covid-19-andstudent-learning-in-the-united-states-the-hurt-could-lasta-lifetime.

10. Santos CC, Coutinho EF, Paillard GAL, Moreira LO. Um relato sobre os desafios das atividades remotas em um curso de graduação presencial diante das medidas de prevenção contra o SARS-CoV-2. Renote. 2020;18(1):1-10.
11. World Health Organization. Stay physically active during self-quarantine. 2020 [cited 2020 aug 25]. Available from: https://www.euro.who.int/en/health-topics/healthemergencies/coronavirus-covid-19/technical-guidance/stayphysically-active-during-self-quarantine.

12. Srivastav AK, Sharma N, Samuel AJ. Impact of Coronavirus disease-19 (COVID-19) lockdown on physical activity and energy expenditure among physiotherapy professionals and students using web-based open E-survey sent through WhatsApp, Facebook and Instagram messengers. Clin Epidemiol Glob Health. 2020 Jul 14. doi: 10.1016/j. cegh.2020.07.003. Epub ahead of print.

13. Peterson NE, Sirard JR, Kulbok PA, DeBoer MD, Erickson JM. Sedentary behavior and physical activity of young adult university students. Res Nurs Health. 2018;41(1):30-8.

14. Wang WY, Hsieh YL, Hsueh MC, Liu Y, Liao Y. Accelerometer-Measured Physical Activity and Sedentary Behavior Patterns in Taiwanese Adolescents. Int J Environ Res Public Health. 2019;16(22):4392.

15. Silva DAS. Nível de atividade física e fatores associados em acadêmicos de educação física de uma universidade pública do nordeste do Brasil. Rev Bras Ativ Fís Saúde. 2016;16(3):193-8.

16. Sandvine. The Global Internet Phenomena Report COVID-19 Spotlight. May 2020. [cited 2020 aug 21]. Available from: https:/www.sandvine.com/ covid-internetsportlight-report.

17. Colley RC, Bushnik T, Langlois K. Exercise and screen time during the COVID-19 pandemic. Health Rep. 2020;31(6):3-11.

18. Constandt B, Thibaut E, Bosscher V, Scheerder J, Ricour M, Willem A. Exercising in Times of Lockdown: An Analysis of the Impact of COVID-19 on Levels and Patterns of Exercise among Adults in Belgium. Int J Environ Res Public Health. 2020;17(11):4144.

19. Melo AB, Carvalho EM, Sá FGS, Cordeiro JP, Leopoldo AS, Lima-Leopoldo AP. Nível de atividade física dos estudantes de graduação em educação física da Universidade Federal do Espírito Santo. J Phys Educ. 2016;27:e2723.

20. Santos T, Leão O, Leite J, Silva M. Atividade física em acadêmicos de Educação Física: um estudo longitudinal. Rev Bras Ativ Fís Saúde. 2017;22(1):76-84.

21. Gallo LA, Gallo TF, Young SL, Moritz KM, Akison LK. The Impact of Isolation Measures Due to COVID-19 on Energy Intake and Physical Activity Levels in Australian University Students. Nutrients. 2020;12(6):1865.

22. Ammar A, Brach M, Trabelsi K, Chtourou H, Boukhris O, Masmoudi L, et al. Effects of COVID-19 Home Confinement on Eating Behaviour and Physical Activity: Results of the ECLB-COVID19 International Online Survey. Nutrients. 2020;12(6):1583.

23. Qin F, Song Y, Nassis GP, Zhao L, Dong Y, Zhao C, et al. Physical activity, screen time, and emotional well-being during the 2019 novel coronavirus outbreak in China. Int J Environ Res Public Health. 2020;17(14):5170.

24. Ruíz-Roso MB, Padilha PC, Matilla-Escalante DC, Brun P, Ulloa N,Acevedo-Correa D, etal. Changes of Physical Activity and Ultra-Processed Food Consumption in Adolescents from Different Countries during Covid-19 Pandemic: An Observational Study. Nutrients. 2020;12(8):e2289.

25. Reyes-Olavarría D, Latorre-Román PÁ, Guzmán-Guzmán IP, Jerez-Mayorga D, Caamaño-Navarrete F, DelgadoFloody P. Positive and negative changes in food habits, physical activity patterns, and weight status during covid-19 confinement: Associated factors in the chilean population. Int J Environ Res Public Health. 2020;17(15):5431. 
26. Carter SJ, Baranauskas MN, Fly AD. Considerations for Obesity, Vitamin D, and Physical Activity Amid the COVID-19 Pandemic. Obesity. 2020;28(7):1176-7.

27. Pitanga FJG, Beck CC, Pitanga CPS. Inatividade física, obesidade e COVID-19: perspectivas entre múltiplas pandemias. Rev Bras Ativ Fís Saúde. 2020;25:e0114.

28. Ranasinghe C, Ozemek C, Arena R. Exercise and well-being during COVID 19-Time to boost your immunity. Expert Rev Ant Infec Ther. 2020; [cited 2020 aug 30]. Available from: https://www.tandfonline.com/doi/full/10.1080/14787 210.2020 .1794818 .
29. Schuch FB, Bulzing RA, Meyer J, Vancampfort D, Firth J, Stubbs B, et al. Associations of moderate to vigorous physical activity and sedentary behavior with depressive and anxiety symptoms in self-isolating people during the COVID-19 pandemic: A cross-sectional survey in Brazil. Psychiat Res. 2020; 292:113339. 